archives-ouvertes

\title{
The rodents from Santpedor-2 (Ebro Basin, NE Spain) confirm the Oligocene age of the latest primates from the Paleogene of Europe
}

\author{
Monique Vianey-Liaud, Raef Minwer-Barakat, Laurent Marivaux
}

\section{To cite this version:}

Monique Vianey-Liaud, Raef Minwer-Barakat, Laurent Marivaux. The rodents from Santpedor-2 (Ebro Basin, NE Spain) confirm the Oligocene age of the latest primates from the Paleogene of Europe. Geobios, Elsevier Masson, In press, 10.1016/j.geobios.2019.06.002 hal-02263896

\section{HAL Id: hal-02263896 \\ https://hal.umontpellier.fr/hal-02263896}

Submitted on 6 Aug 2019

HAL is a multi-disciplinary open access archive for the deposit and dissemination of scientific research documents, whether they are published or not. The documents may come from teaching and research institutions in France or abroad, or from public or private research centers.
L'archive ouverte pluridisciplinaire HAL, est destinée au dépôt et à la diffusion de documents scientifiques de niveau recherche, publiés ou non, émanant des établissements d'enseignement et de recherche français ou étrangers, des laboratoires publics ou privés. 
Original article

\title{
The rodents from Santpedor-2 (Ebro Basin, NE Spain) confirm the Oligocene age of the latest primates from the Paleogene of Europe $e^{\frac{\pi}{2}}$
}

\author{
Monique Vianey-Liaud ${ }^{\mathrm{a}}$, Raef Minwer-Barakat ${ }^{\mathrm{b}, \mathrm{c}, *}$, Laurent Marivaux ${ }^{\mathrm{a}}$ \\ a Institut des Sciences de l'Évolution de Montpellier (ISE-M), UMR 5554, CNRS, UM, IRD, EPHE, c.c. 064, Université de Montpellier, place Eugène-Bataillon, \\ 34095 Montpellier Cedex 05, France \\ ${ }^{\mathrm{b}}$ Institut Català de Paleontologia Miquel Crusafont, Universitat Autònoma de Barcelona, Cerdanyola del Vallès, Barcelona 08193, Spain \\ ' Departamento de Estratigrafía y Paleontología, Universidad de Granada, Avda. Fuente Nueva s/n, 18071 Granada, Spain
}

\section{A R T I C L E I N F O}

\section{Article history:}

Received 21 January 2019

Accepted 21 June 2019

Available online $\mathrm{xxx}$

\section{Keywords:}

Rodentia

Early Oligocene

Rupelian

Grande Coupure

Iberian Peninsula

\begin{abstract}
A B S T R A C T
This paper provides a revised and updated description and identification of the rodents from Santpedor2 (northeastern Spain). The age of this locality is particularly relevant, because it is one of the few European sites assigned to the early Oligocene that has yielded primate remains. However, the rodent assemblage from this site has never been described in detail, and therefore the Oligocene age of this locality remained tentative. Despite the scarcity of the material, the rodents from Santpedor-2 are characteristic enough either to be identified as already known species, or at least compared with close species. Eight different rodent taxa were recognized. Among them, the theridomyid Ectropomys exiguus, which is recorded only in late Eocene localities, and the glirid Glamys devoogdi, which is known in both latest Eocene and early Oligocene localities. The other taxa are found only in Oligocene localities, and consist of the theridomyid Paratheridomys margaritae and members of two families that arrived in Europe at the beginning of the Oligocene: eomyids (Eomys sp.) and cricetids (Eucricetodon atavus, cf. Heterocricetodon sp., cf. Pseudocricetodon sp.). Finally, another theridomyid (Issiodoromyinae) seems to correspond to a new species and new genus, the main features of which correspond to early Oligocene evolutionary grades. This rodent assemblage from Santpedor- 2 is assigned to the early Oligocene, mainly on the basis of the presence of immigrant rodents that reached Europe in relation with the Grande Coupure (cricetids and eomyids). This dating is notably supported by the presence of $P$. margaritae together with Glamys devoogdi, both being found in Hoogbutsel (early Rupelian, MP21). Only one rodent (E. exiguus) represents an Eocene relict, as is the case of Pseudoloris, the only primate recorded in this locality. Therefore, this study supports the Oligocene age of Santpedor-2 and then the persistence of omomyid primates in the Iberian Peninsula (at least locally) after the Grande Coupure.
\end{abstract}

\section{Introduction}

The fossil site of Santpedor (Ebro Basin, NE Spain), originally named as "Costa de la Vila", was first mentioned in the 1950's, when Masachs et al. (1954) briefly described the presence of two perissodactyls and an artiodactyl: Paleotherium medium, Plagiolophus annectens, and an undetermined Anoplotheriidae (later referred to Anoplotherium commune by Golpe, 1982). These authors assigned the locality to the late Eocene. In the 1980's, the teams of the Institut de Paleontologia de Sabadell (now Institut Català de

\footnotetext{
Corresponding editor: Gilles Escarguel.

* Corresponding author.

E-mail address: raef.minwer@icp.cat (R. Minwer-Barakat).
}

Paleontologia Miquel Crusafont, ICP) and the Universidad de Barcelona decided to resume the study of this locality. On the one hand, they revisited the macromammal remains first reported by Masachs et al. (1954), noting that the material was so scarce that it could not be determined at the specific level and did not allow for a precise dating of the locality. Therefore, according to Arbiol and Sáez (1988), the faunal list of the classical site of Santpedor consisted of Paleotherium sp., Plagiolophus sp. and Anoplotheriidae indet. On the other hand, these teams returned and prospected the area in order to find levels with micromammal remains. Agustí et al. (1987) and Arbiol and Sáez (1988) described a rodent-bearing site that they called Santpedor-2, placed $350 \mathrm{~m}$ east from the classical locality of Santpedor, and situated in the same stratigraphic level (Fig. 1). These authors reported in Santpedor-2 the presence of four different rodents: Theridomys 


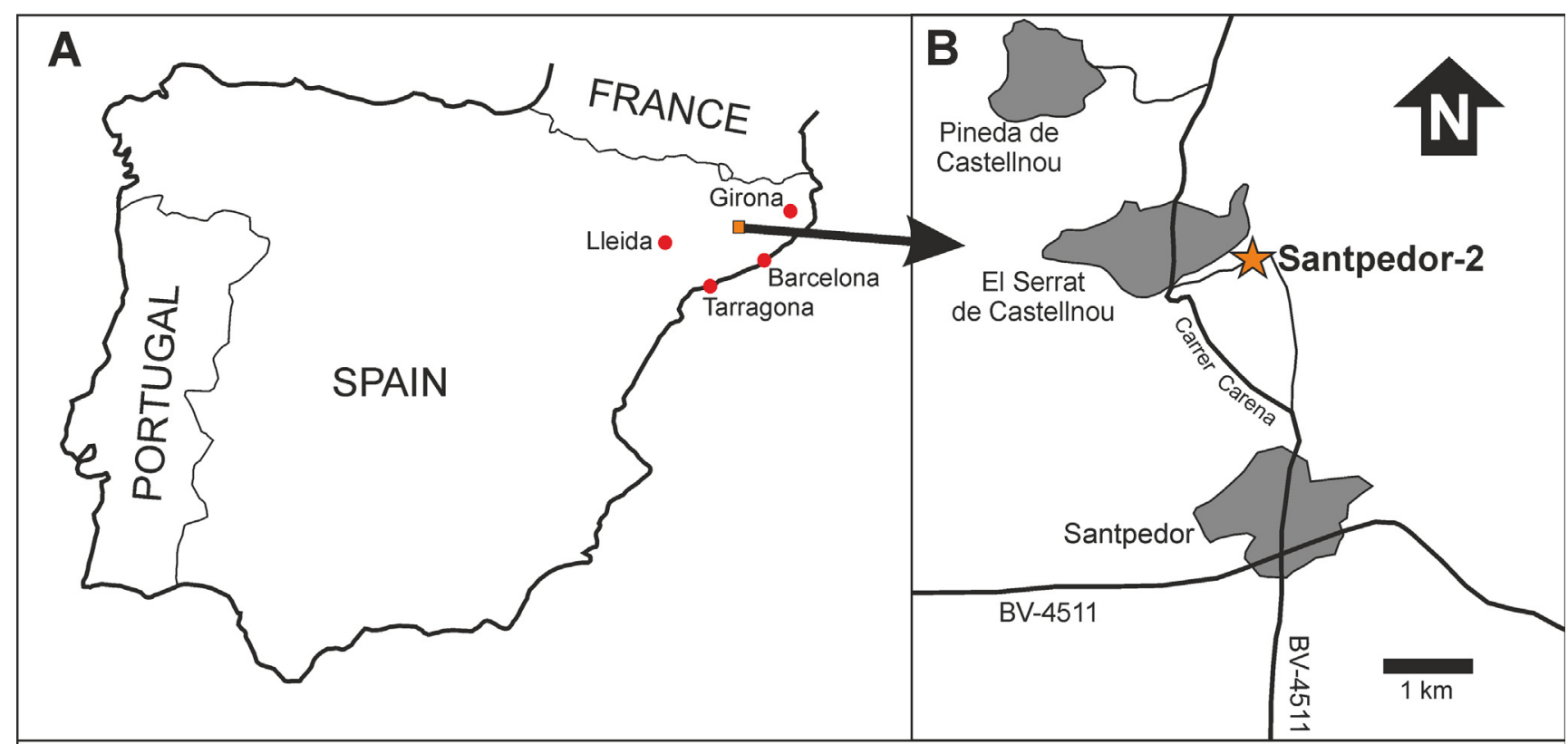

C

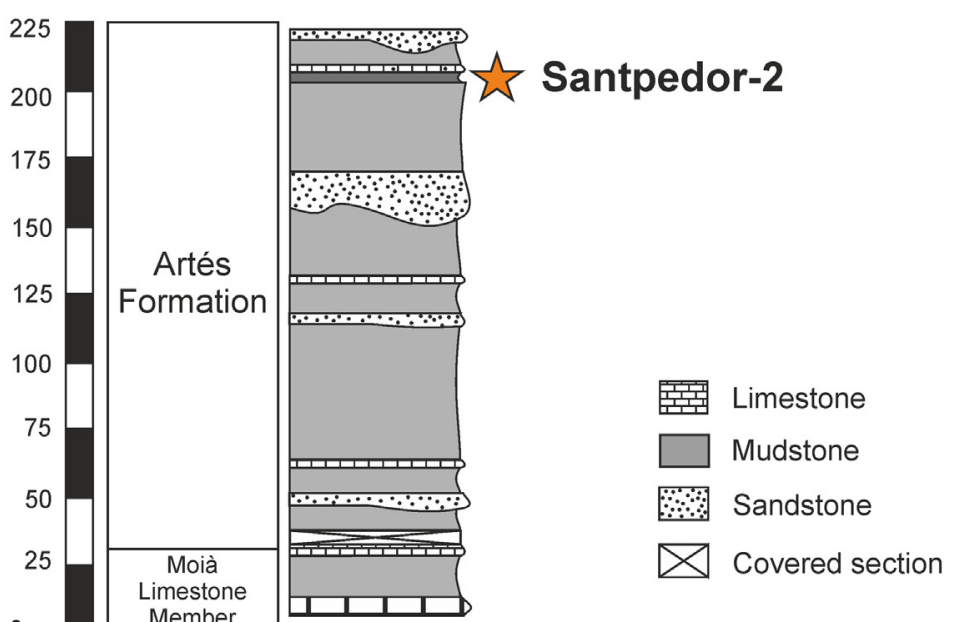

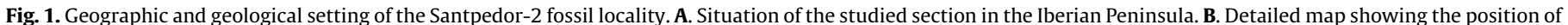

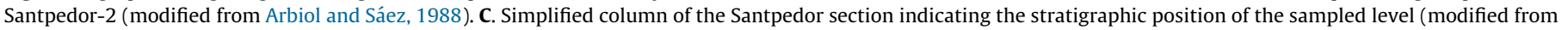
Costa et al., 2011).

aff. aquatilis, Gliravus aff. priscus, Eucricetodon atavus, and Pseudoltinomys gaillardi. Based on this rodent assemblage, they assigned the locality to the early Oligocene, an age maintained in several later works (Cuenca et al., 1992; Aguilar et al., 1997; Köhler and Moyà-Solà, 1999; Barberà et al., 2001; Hooker et al., 2007; Hooker, 2010; Minwer-Barakat et al., 2010, 2012, 2013, 2015; Costa et al., 2011; Marigó et al., 2014; Sanjuan et al., 2014). Even more, Agustí et al. (1987) proposed a biozone based on the rodent assemblage from Santpedor-2. They defined the Theridomys aff. aquatilis zone, which would represent the earliest Oligocene mammal level (MP21), thereby being correlated with the locality of Hoogbutsel in Belgium. However, neither Agustí et al. (1987) nor Arbiol and Sáez (1988) provided descriptions, measurements or illustrations of the rodent material from Santpedor-2, and their taxonomic ascriptions remained non verifiable as a result.

The relevance of this locality increased when Köhler and Moyà-Solà (1999) reported the presence of scarce primate remains in Santpedor-2 and in the nearby and somewhat younger locality of Fonollosa-13. The fossil primates from Santpedor-2 consisted of two fragments of lower molars, whereas those from Fonollosa-13 documented an upper tooth row, the dental morphology of which allowed to undoubtedly assign them to the genus Pseudoloris. Interestingly, primates were so far supposed to have disappeared from Europe in relation to the drastic cooling recorded at the Eocene-Oligocene transition and the subsequent faunal turnover that dramatically affected continental vertebrate fauna, known as the "Grande Coupure". The finding of Pseudoloris ( $P$. godinoti) from Santpedor-2 and Fonollosa-13 represented the unique record of Oligocene primates in the continent, a presence that was shortly after confirmed by the discovery of a single lower molar of the genus Microchoerus in the early Oligocene locality of Aguatón, also in Spain (Peláez-Campomanes, 2000). However, the age proposed for Santpedor was based only on the faunal list 
provided by Agustí et al. (1987) and Arbiol and Sáez (1988) and, despite the fact that the interest of the locality lies precisely on its Oligocene age, a detailed study of its rodents was never developed.

In this paper we present a thorough study of the rodents from Santpedor-2. The rodent assemblage from this site includes eight different forms of theridomyids, eomyids, cricetids and glirids, and is therefore more diverse than previously thought. The detailed study of these rodents supports the early Oligocene age of the locality.

\section{Geological setting}

The Ebro Basin is the southern foreland basin of the Pyrenean Range, which was formed in response to convergence and collision between the Iberian and European plates from the Late Cretaceous to the Miocene (Puigdefàbregas et al., 1992; Busquets et al., 2003). This basin is delimited by three mountain ranges formed during the Eocene-Oligocene compression: the Pyrenees to the North, the Iberian Range to the Southwest, and the Catalan Coastal Ranges to the Southeast. The marine connection of the Ebro Basin was interrupted during the Priabonian (the marine-continental transition has been precisely dated at $\sim 36.0$ Ma by Costa et al., 2010). From the late Eocene to the late Miocene, the Ebro Basin displayed a closed drainage system, and its depositional framework consisted of distributive alluvial systems fed from the tectonically active surrounding ranges, laterally changing to shallow lacustrine zones (Agustí et al., 1987; Barberà et al., 2001; Sáez et al., 2007). The basin infill (up to $2000 \mathrm{~m}$ thick) consists therefore of alluvial, fluvial and lacustrine deposits, in which several vertebrate sites have been identified (Agustí et al., 1987; Anadón et al., 1987; Cuenca et al., 1992). Nevertheless, mammal sites corresponding to the earliest phase of endorheic sedimentation are relatively scarce: the only two localities assigned to the late Eocene (Priabonian, MP19/20) are Sant Cugat de Gavadons (Crusafont-Pairó, 1967; Hooker et al., 2009; Minwer-Barakat et al., 2013, 2016) and Rocafort de Queralt (Anadón et al., 1987), while the first mammal site that, according to the published data, postdates the "Grande Coupure" is Santpedor (Köhler and Moyà-Solà, 1999; Barberà et al., 2001; Costa et al., 2011).

\section{Material and methods}

The described rodent specimens from Santpedor-2 consist of 33 isolated teeth, housed in the collections of the Institut Catala de Paleontologia Miquel Crusafont (Sabadell, Barcelona, Spain). The nomenclature used in the descriptions (Fig. 2) follows VianeyLiaud and Marivaux (2017) for theridomorphs, Dienemann (1987) for cricetids, Vianey-Liaud (1994) for glirids, and Maridet et al. (2010) for eomyids. Measurements (Table 1) were taken using an optic calliper "Nikon measuroscope 10" connected to a monitor "Nikon SC112"; measured parameters include the mesiodistal maximum length and the maximum width perpendicular to the length, taken in keeping the wear surface horizontal. Micrographs were obtained using the Environmental Scanning Electron Microscope (ESEM) at the Universitat de Barcelona.

\section{Systematic paleontology}

Class Mammalia Linnaeus, 1758

Order Rodentia Bowdich, 1821

Family Theridomyidae Alston, 1876

Subfamily Oltinomyinae Hartenberger, 1971

Genus Ectropomys Bosma et Schmidt-Kittler, 1972

Ectropomys exiguus Bosma et Schmidt-Kittler, 1972
Fig. 3(A-C)

Material: DP4: IPS 105269; p4: IPS 105286, m2: IPS 105287. Description:

Upper teeth. The unique upper tooth is a DP4 (Fig. 3(A)), the lingual side of its crown being relatively high and narrow with respect to the buccal one; it is not anteriorly reduced. The postprotocrista makes the high endoloph, which does not join the hypocone, and then the syncline II communicates with the shallow and narrow sinus. The high anteroloph joins the paracone to the protocone, closing the syncline I (anteroflexus) buccally. The continuous protoloph joins the apex of the protocone. The mesoflexus (syncline II + syncline I) is closed buccally by the mesostyle and the extensions of the postparacrista mesially and of the premetacrista distally. The mesoloph is lower than the other lophs and breaks at mid-length. Its buccal part weakly attaches its lingual part, which fuses with the thicker lingual metaloph. The mesoloph separates the long buccolingually syncline II and the shorter syncline III. The buccal metaloph is transverse but slightly mesially oriented, connected to the lingual metaloph, and separated from the long posteroloph. As a result, the syncline IV is more developed than on the known populations of E. exiguus or E. monacensis. This syncline IV could be subdivided into a much worn DP4, since a very low bead is visible at its bottom both on the distal flank of the buccal metaloph and on the lingual flank of the posteroloph.

Lower teeth. The p4 from Santpedor-2 (Fig. 3(B)) is more worn than that of Rocafort de Queralt, the front part of the latter being incomplete. It shows a break from the entoconid to the sinusid. On this $\mathrm{p} 4$, the protoconid and the larger metaconid are linked by a complete transverse metalophulid I. The latter is notched mesially by a short antesinusid, limited mesially by a low anterolophid. A high postmetacristid joins the mesostylid. The mesostylid is connected to a mesolophid that reaches the mesoconid swelling at the distal end of a strong postprotocristid. The synclinid II is divided by a short mesiodistal cristid, extending from the mesolophid to the metaconid. The synclinid III is closed lingually. The short distal ectolophid is separated by a notch from the mesoconid swelling. The entolophid and posterolophid are high and complete, between the strong entoconid and hypoconid. The morphology of $\mathrm{m} 2$ (Fig. 3(C)) is reminiscent to that of the tooth from San Cugat de Gavadons, in which the small anteroconid is framed by the anterolophid and anterocingulid, which delimit narrow anteroflexid and antesinusid. The sinusid is slightly deeper transversely, and the mesolophid is complete, reaching the mesostylid-postmetacristid junction.

Remarks: The teeth are larger than those of Ectropomys exiguus from the Isle of Wight, Rocafort de Queralt and San Cugat de Gavadons, but they are clearly smaller than Oltinomys platyceps (Bosma and Schmidt-Kittler, 1972; Vianey-Liaud et al., 1994). The general features of these teeth are compatible with the species E. exiguus, whereas the few differences are more derived than in the material from the above mentioned localities (larger size, much more marked lophodonty, higher crown, deeper sinusid). These characteristics argue for a form younger than the late Eocene populations of $E$. exiguus.

Subfamily Theridomyinae Alston, 1876

Genus Paratheridomys Vianey-Liaud et Marivaux, 2017

Paratheridomys margaritae (Vianey-Liaud, 1972)

Fig. 3(D-F)

Material: M2: IPS 18941; M3: IPS 105257; m3: IPS 105284.

\section{Description:}

Upper molars. The mesial and distal flanks of the crown are relatively flat, vertical and parallel on M2 (Fig. 3(D)). This tooth is worn, and the wear reduces the posterosyncline (syncline IV) to an islet. The paracone, mesostyle and metacone are slightly bulged. 


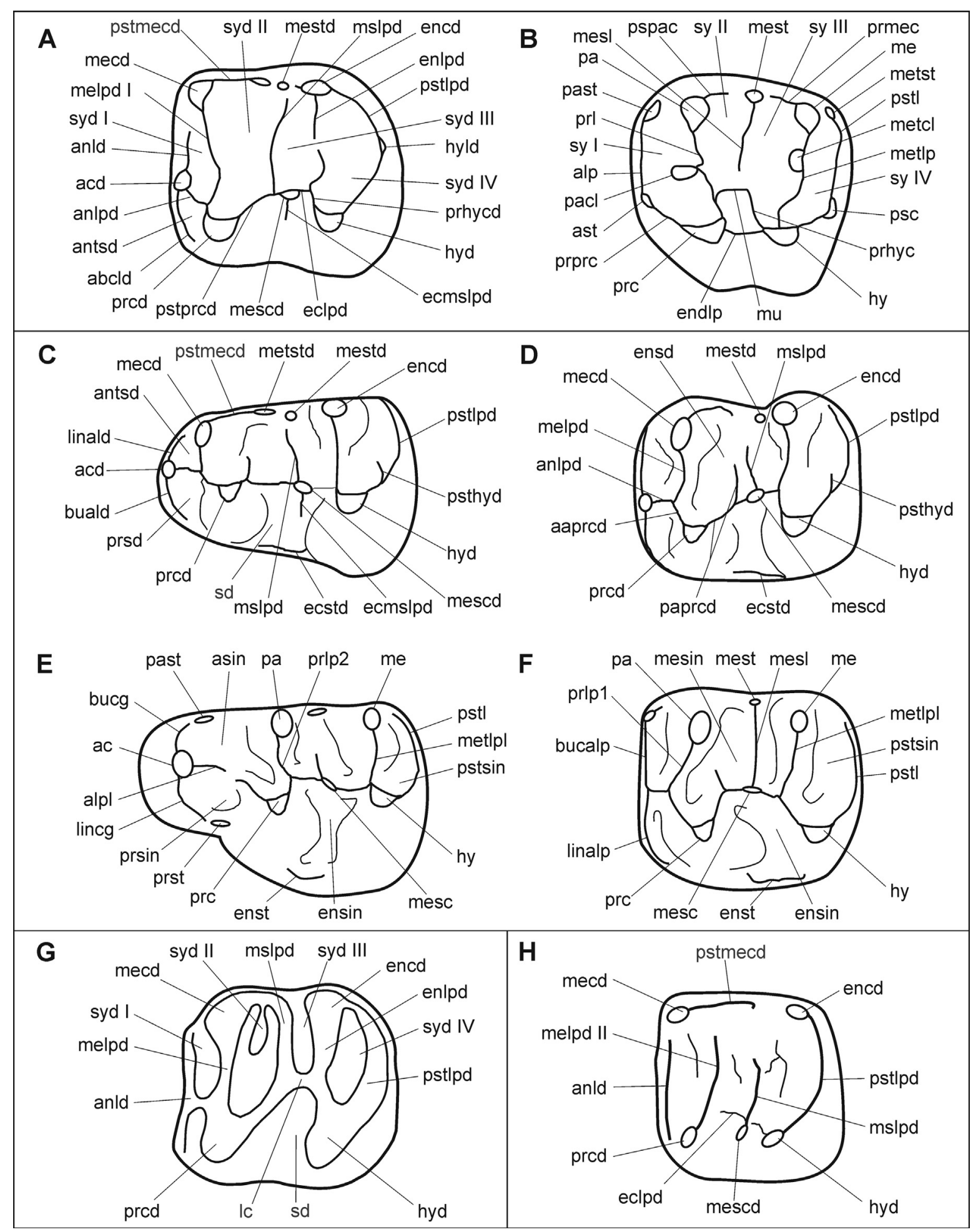

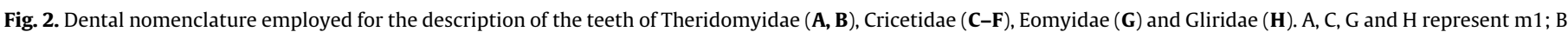

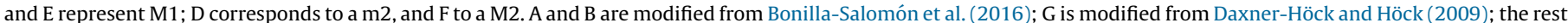

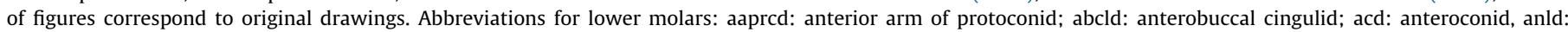

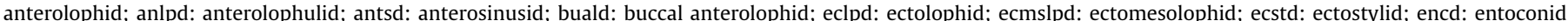

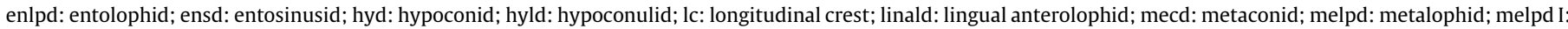

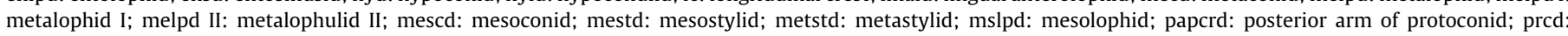

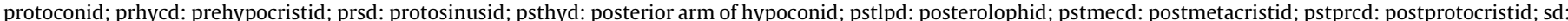

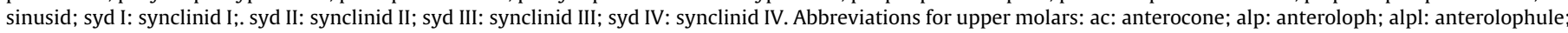

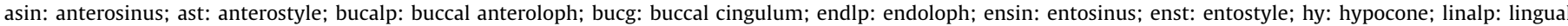

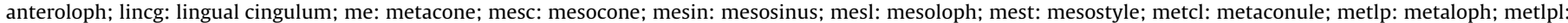

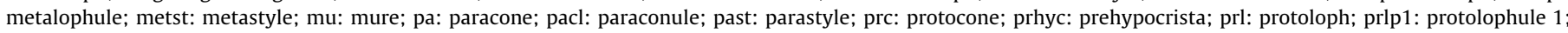

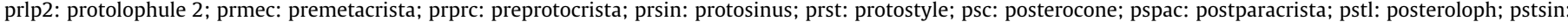
posterosinus; sy I: syncline I;. sy II: syncline II; sy III: syncline III; sy IV: syncline IV. 
Table 1

Measurements (in $\mathrm{mm}$ ) of the rodent teeth from Santpedor-2.

\begin{tabular}{|c|c|c|c|c|}
\hline Taxon & Catalogue number & Tooth & Length & Width \\
\hline \multirow[t]{3}{*}{ Ectropomys exiguus } & IPS 105269 & DP4 & 1.66 & 1.86 \\
\hline & IPS 105287 & $\mathrm{~m} 2$ & 1.91 & 1.80 \\
\hline & IPS 105286 & p4 & 1.75 & 1.44 \\
\hline \multirow[t]{3}{*}{ Paratheridomys margaritae } & IPS 18941 & M2 & 1.94 & 2.63 \\
\hline & IPS 105257 & M3 & 1.96 & 2.23 \\
\hline & IPS 105284 & $\mathrm{~m} 3$ & - & 1.72 \\
\hline \multirow[t]{11}{*}{ Issiodoromyinae nov. gen., nov sp. } & IPS 105276 & P4 & 2.23 & 2.69 \\
\hline & IPS 105275 & M1-2 & 2.16 & 2.72 \\
\hline & IPS 105277 & M1-2 & 2.03 & 2.75 \\
\hline & IPS 105278 & M1-2 & - & - \\
\hline & IPS 105279 & M3 & 2.20 & 2.69 \\
\hline & IPS 105280 & M3 & 2.03 & 2.42 \\
\hline & IPS 18940 & $\mathrm{dp} 4$ & 2.14 & 1.41 \\
\hline & IPS 105281 & $\mathrm{p} 4$ & 2.35 & 1.97 \\
\hline & IPS 105282 & $\mathrm{~m} 2$ & 2.39 & 2.07 \\
\hline & IPS 105283 & $\mathrm{~m} 3$ & 2.30 & 1.93 \\
\hline & IPS 105285 & $\mathrm{~m} 3$ & - & - \\
\hline \multirow[t]{2}{*}{ Eomys sp. } & IPS 105265 & $\mathrm{p} 4$ & 1.08 & 1.03 \\
\hline & IPS 105262 & $\mathrm{~m} 1-2$ & - & 1.09 \\
\hline \multirow[t]{3}{*}{ Eucricetodon atavus } & IPS 105268 & M1 & 1.92 & 1.23 \\
\hline & IPS 105266 & M2 & 1.32 & - \\
\hline & IPS 105264 & M3 & - & - \\
\hline \multirow[t]{7}{*}{ cf. Heterocricetodon sp. } & IPS 105273 & M1 & - & - \\
\hline & IPS 105258 & M2 & 1.50 & 1.48 \\
\hline & IPS 105260 & M2 & 1.51 & - \\
\hline & IPS 105267 & M3 & 1.18 & 1.24 \\
\hline & IPS 105259 & $\mathrm{~m} 1$ & 1.72 & 1.23 \\
\hline & IPS 105261 & $\mathrm{~m} 2$ & - & - \\
\hline & IPS 105263 & $\mathrm{~m} 3$ & 1.58 & 1.33 \\
\hline cf. Pseudocricetodon sp. & IPS 105274 & $\mathrm{~m} 2$ & - & 1.19 \\
\hline \multirow[t]{3}{*}{ Glamys devoogdi } & IPS 105272 & $\mathrm{p} 4$ & 0.93 & 0.86 \\
\hline & IPS 105270 & $\mathrm{~m} 2$ & 1.01 & 1.11 \\
\hline & IPS 105271 & $\mathrm{~m} 2$ & - & - \\
\hline
\end{tabular}

The protocone is not strongly pinched, and rather appears only slightly stretched obliquely (mesiobuccal to distolingual), giving the same orientation to the sinus. The syncline I and syncline II are equally long and shorter than syncline III. The enamel of the distal flank of the protocone is only a little thinner than on the mesial flank; the enamel of the hypocone and of its arms is particularly thick, and as thick as the distal border of the crown.

Lower molar. Only one $\mathrm{m} 3$ can be referred to this species (Fig. 3(F)). There is no synclinid I; the metalophid I is mesial and the synclinid II is not compressed. The postmetacristid is high and joins the mesostylid at the lingual extremity of the transverse mesolophid. The postprotocristid is not markedly oblique and it joins the (pseudo)mesoconid at the mesial extremity of the short and slightly oblique buccomesial to distolingual short ectolophid. The synclinid II is nearly as long as the synclinid IV, but wider. Synclinid III and synclinid IV are equal in width.

Remarks: The characters of the upper molars described above are found on the M2 of the type population from Hoogbutsel (Belgium, MP21; Vianey-Liaud, 1972, 1989). These teeth differ from those of Blainvillimys langei in their more regular enamel thickness, their lower crown, less pinched protocone and less oblique sinus. The features of the $\mathrm{m} 3$ described above are very similar to those of the $\mathrm{m} 3$ of $P$. margaritae lacking synclinid I from Hoogbutsel (Vianey-Liaud, 1972). The $m 3$ from Santpedor is lower crowned, with a more regular enamel thickness and less oblique posprotocristid than the $\mathrm{m} 3$ of $B$. langei. The teeth from Santpedor differ from Theridomys aquatilis in their smaller size.

?Issiodoromyinae Tullberg, 1899

?Issiodoromyinae nov. gen., nov. sp.

Fig. 3(G-Q)

Material: P4: IPS 105276; M1-2: IPS 105275, 105277, 105278; M3: IPS 105279, 105280; dp4: IPS 18940; p4: IPS 105281; m2: IPS 105282; m3: IPS 105283, 105285.

\section{Description:}

Upper teeth. The crowns of the P4 and M1-2, and probably of the worn M3, show a constriction of the outline at the levels of the termination of the anterior arm of the protocone (at the junction with the anteroloph) and of the posterior arm of the hypocone (at its junction with the posteroloph). These shrinkings, well distinct on the less worn teeth only, are never observed on the M1-2 of Paratheridomys margaritae, Theridomys aquatilis, and Blainvillimys langei, as well as on M1-2 of any species of Pseudoltinomys. On the P4 and M1-2, the paracone and metacone are markedly bulged and the protoloph and metaloph are thick. The mesoloph is thinner and lower than these lophs. On P4 (Fig. 3(G)), the anteroloph is short but the anterosyncline (syncline I) is longer than in the late Eocene and Oligocene species of Pseudoltinomys. The posteroloph is short, and the posterosyncline is particularly reduced, even on the weakly worn M1-2 IPS 105275 (Fig. 3(H)). The sinus is shorter buccolingually than the opposite syncline II, or has similar length in the most worn teeth. Contra what is seen on Pseudoltinomys, the sinus and the syncline II are not communicating: they are separated by a very short mure as seen on the weakly worn M1-2 (Fig. 3(H)).

Lower teeth. The dp4 (Fig. 3(M)) is slightly shorter than p4 (Fig. $3(\mathrm{~N})$ ), and the latter is similar in length then that of the $\mathrm{m} 2$ and $\mathrm{m} 3$. On $\mathrm{dp} 4$, the weak protoconid and the following postprotocristid are lowered by wear, and then the metaconid and entoconid remain higher. There is a very low mesiodistal ridge descending from the metaconid to the middle of the mesolophid. The latter is complete, and joins the postmetacristid at the mesostylid level. The lingual opening of the synclinid III is narrow. The sinusid is buccolingually short. The long and curved posterolophid is thickened at the hypoconulid level, lingually to the oblique posthypocristid. On the unworn $\mathrm{p} 4$, the metaconid connects to the protoconid by a high mesial metalophid. There is no antesinusid. The mesolophid is slightly lower than the metaand ento- lophids. The mesolophid is broken before joining the mesostylid level by a short and narrow notch. The synclinid II displays a short and weak mesiodistal ridge. The ectolophid is short, showing a very shallow and narrow break in its middle. The synclinid III is lingually open. The sinusid is buccolingually shorter than the synclinid III. The entolophid is as high as the other lophids, and the posterolophid is long, without distinct swelling at the hypoconulid level.

The $\mathrm{m} 2$ (Fig. $3(\mathrm{O})$ ) is worn and the enamel shows a similar thickness on the mesial, buccal and distal surfaces of the crown. There is an indication of the presence of an antesinusid as an angle on the mesial face of the metalophulid I. The synclinid II is divided by a mesiodistal ridge. The sinusid is oblique and directed to the buccal end of the synclinid IV. The synclinid II is closed lingually, the synclinid III open, and the synclinid IV shallowly and narrowly open. The m3 IPS 105283 (Fig. 3(P)) displays the same features as those of the $\mathrm{m} 2$, and, as it is more worn, the synclinid III and synclinid IV are weakly closed lingually. A very narrow break is observed between the oblique sinusid and the synclinid IV. As for the $\mathrm{m} 2$, an angle of enamel on the metalophulid I indicates the presence of a possible antesinusid. It is well marked on the $\mathrm{m} 3$ IPS 105285 (Fig. 3(Q)).

Remarks: This material documents the best represented species of theridomyid from Santpedor-2. It was previously referred to Pseudoltinomys gaillardi (see Section 1). Nevertheless, these teeth show strong differences with this species, and moreover, with the genus Pseudoltinomys, like the absence of break of the longitudinal crest on upper teeth, the reduced antesinusid or the relatively larger $\mathrm{p} 4$. It would be necessary to get more material to define a new species, as it appears to be, and probably also a new genus. The teeth have been directly compared with several theridomyid species from the late Eocene and early 
A
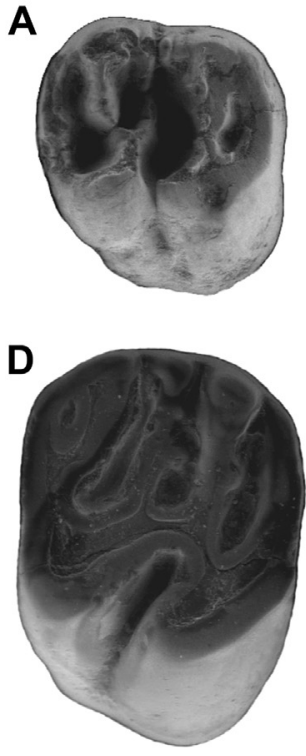

B

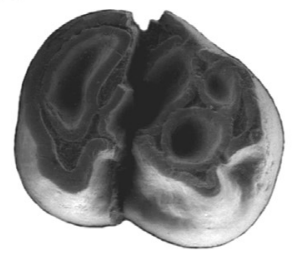

E

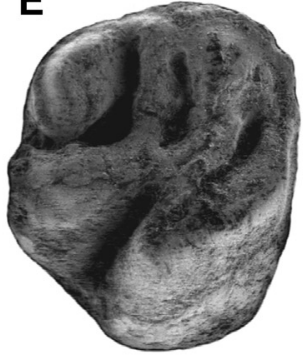

C

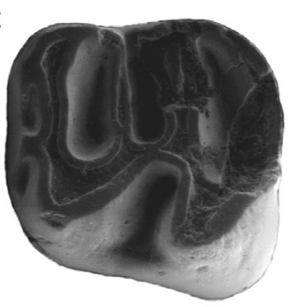

F

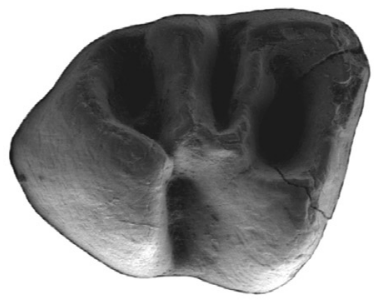

G
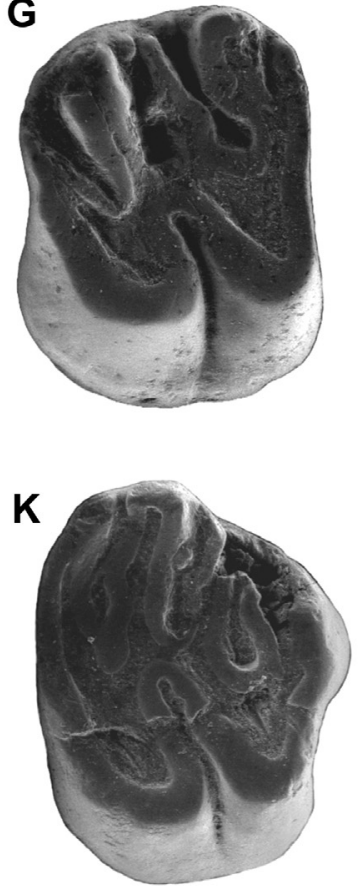

H

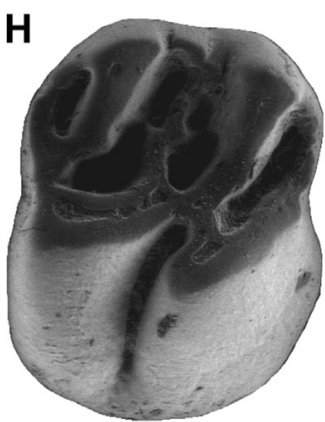

L

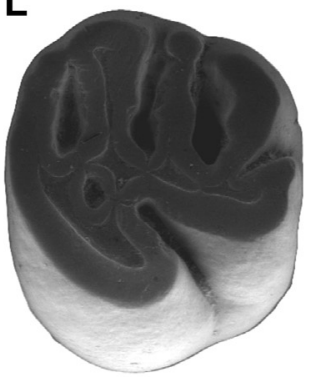

I

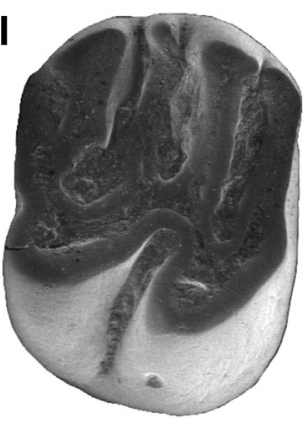

M
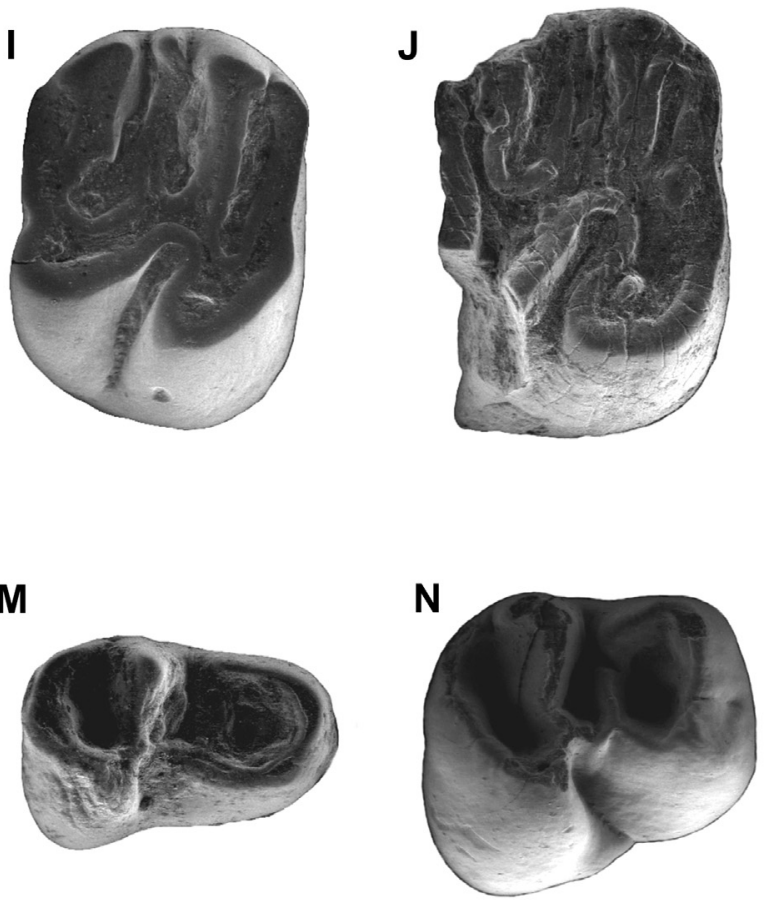
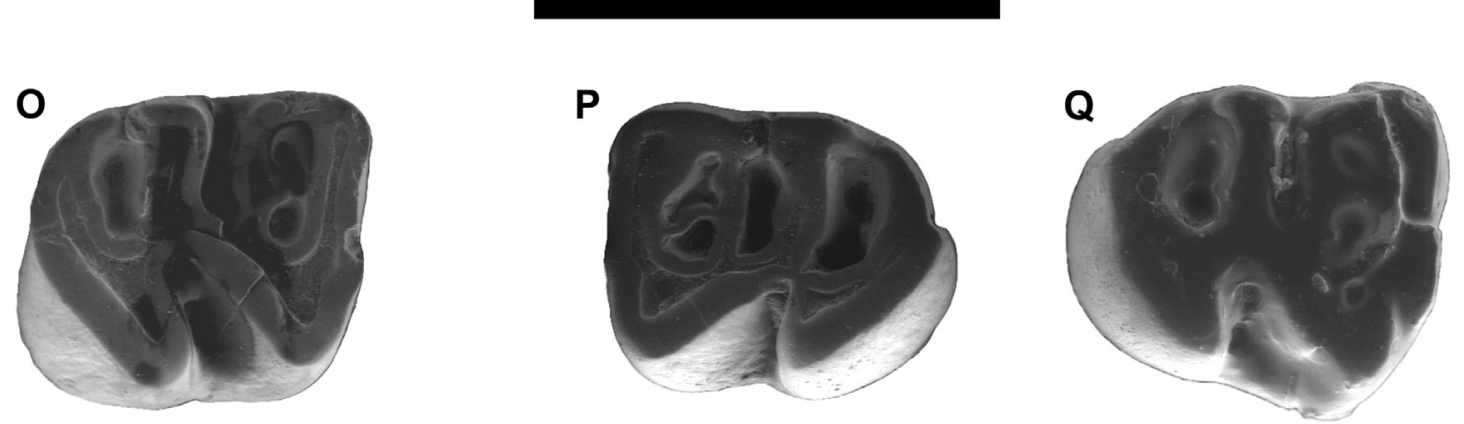

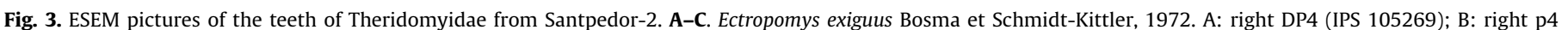

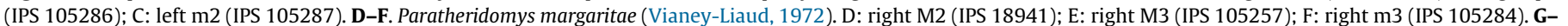

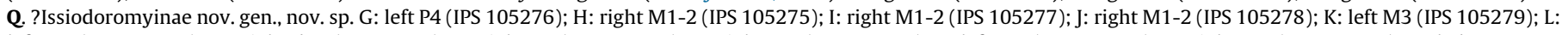

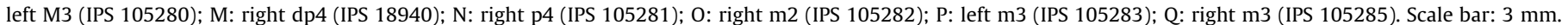


Oligocene localities of Spain and Southern France: San Cugat de Gavadons, Calaf and Los Barros (Ebro Basin, Spain); Civrac, SaintCapraise-d'Eymet and Soumailles (Aquitaine Basin); Escamps, Sainte-Néboule, Aubrelong 1 and Ravet (Quercy Phosphorites); Ronzon (Auvergne). The size is larger than that of Pseudoltinomys aff. cuvieri from San Cugat de Gavadons and P. gaillardi from Soumailles, Ronzon, or from the Quercy localities (Vianey-Liaud, 1976). The deciduous lower molar is simpler than that of P. gaillardi; it is less hypsodont and simpler than that of P. amblesi (Garzon Heydt and López Martínez, 1978). The p4 has its mesial width less reduced with respect to the distal width compared with $\mathrm{p} 4$ of $P$. cuvieri, P. gaillardi, Paratheridomys margaritae and Blainvillimys langei. The crown is lower than in P. gaillardi. Compared to the species of Theridomys, it is close to the size of the smallest teeth of T. aquatilis, and smaller than T. golpei and T. calafensis (Anadón et al., 1987). In addition, the dp4 and p4 are simpler and shorter than in Theridomys.
Family Eomyidae Depéret et Douxami, 1902

Genus Eomys Schlosser, 1884

Eomys sp.

Fig. 4(A, B)

Material: p4: IPS 105265; fragment of m1-2: IPS 105262.

Description and remarks: The size of these teeth is larger than that of Eomys antiquus, close to that of E. molassicus (Engesser, 1987), and slightly smaller than that of E. zitteli (Comte and VianeyLiaud, 1989). However, some features of these two teeth differ from the latter two species. The p4 of Eomys sp. (Fig. 4(A)) is less elongated, and its metaconid and protoconid are more robust than on E. zitteli. Contrary to E. antiquus, E. molassicus and E. zitteli, in the teeth from Santpedor the anteroconid/anterolophid is absent: there is only a high mesial connection between the protoconid and the metaconid, which is the metalophulid I. These cuspids are closer to each other than on E. molassicus, on which the 'trigonid' appears less short buccolingually than on the species from
A

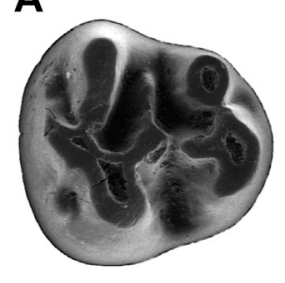

B

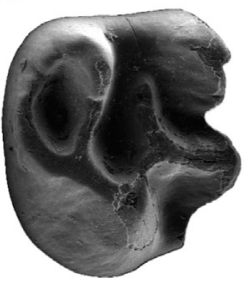

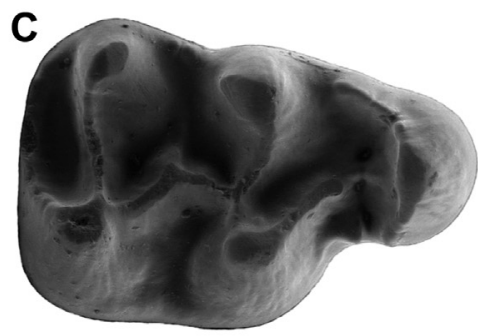

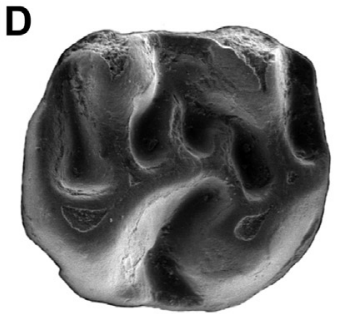

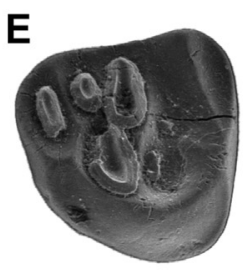

$\mathbf{F}$

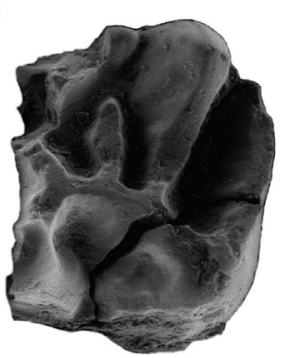

J

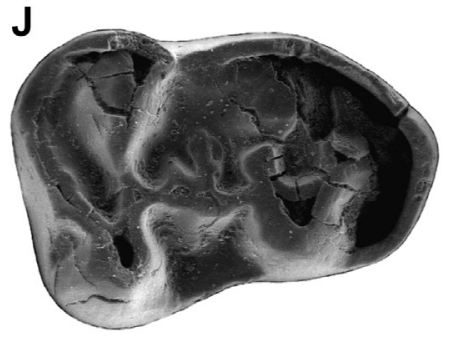

G

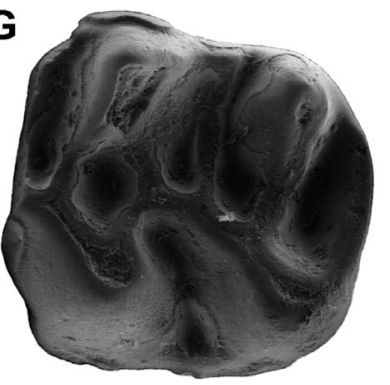

K

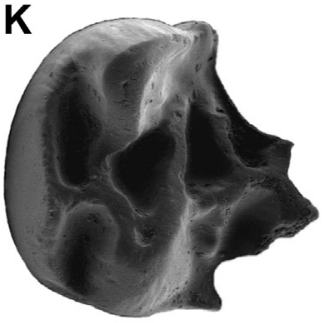

H

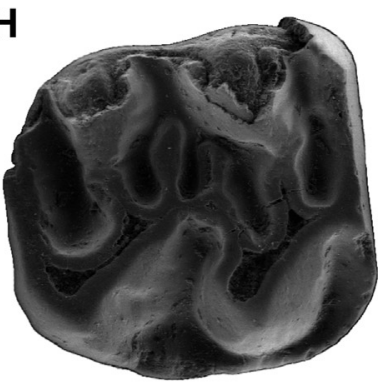

$\mathbf{L}$

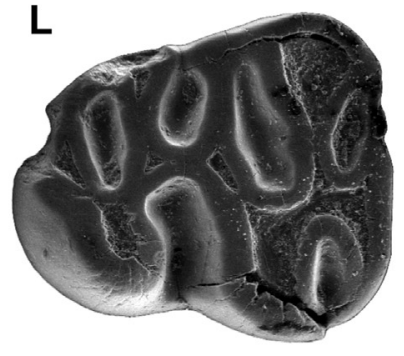

0

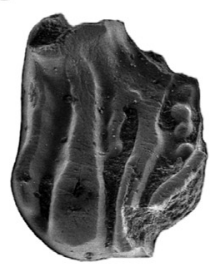

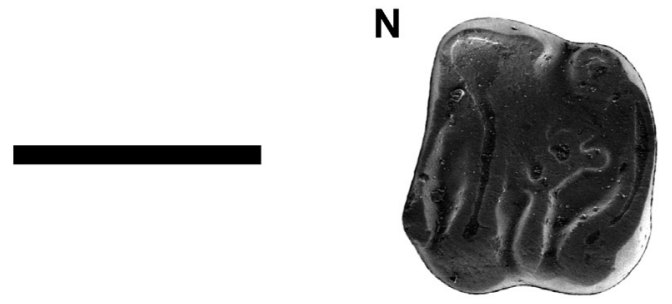

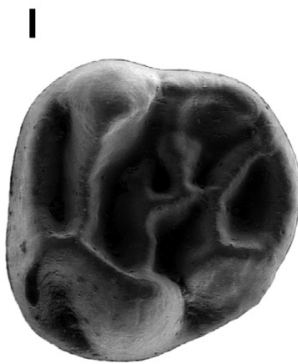

M

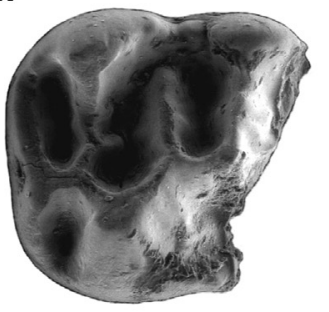

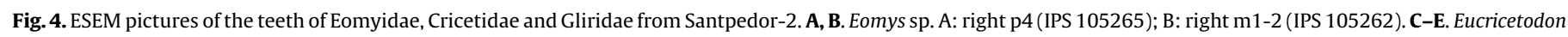

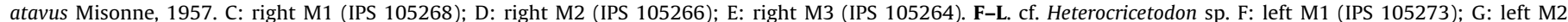

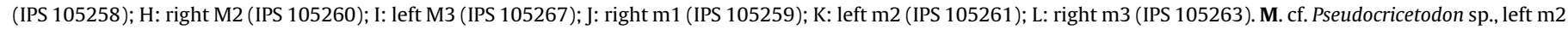
(IPS 105274). N-P. Glamys devoogdi (Bosma et de Bruijn, 1979). N: left m2 (IPS 105270); O: left m2 (IPS 105271); P: right p4 (IPS 105272). Scale bar: 1 mm. 
Santpedor. On p4 and $\mathrm{m} 2$, the mesolophid is moderately long as observed on E. zitteli or on the Eomys sp. from Möhren 20 (Maridet et al., 2010). It is longer than on the type of E. zitteli, but shorter and weaker than on E. molassicus. On the latter (type from Oensingen), it makes an angle, being firstly directed posteriorly before being transverse, whereas it is transverse since the mesoconid on Eomys sp. from Santpedor. On the fragment of m2 IPS 105262 (Fig. 4(B)), the attachment of the entolophid on the posterolophid is more buccal than on E. molassicus, and thus the posterosynclinid and the posterolophid are longer mesiodistally. Therefore, the species from Santpedor displays original features.

Family Cricetidae Rochebrune, 1883

Remarks: When studying the rare cricetid teeth from Santpedor-2, we were confronted with the absence or incompleteness of diagnosis for several Oligocene species or genera. The history of these European Oligocene cricetids, resulting from several phases of immigration and local developments in Western Europe, is complex. An exhaustive review with direct comparison of populations from numerous localities in this geographical area would be essential to achieve consistent results. It would be necessary to take into account all their features, dental (morphology and ultrastructure) and cranial.

Subfamily Eucricetodontinae Mein et Freudenthal, 1971

Genus Eucricetodon Thaler, 1966

Eucricetodon atavus Misonne, 1957

Fig. 4(C-E)

Material: M1: IPS 105268; M2: IPS 105266; M3: IPS 105264. Description:

M1. The enamel of the outskirts of the crown is wrinkled. The buccal side is convex. There is only a single anterocone, from which a weak anterocone spur slopes and joins the long protocone spur. Lingually, the anteroloph slopes to the level of the protostyle, from which it is separated by a notch. Buccally, the cingulum is longer and stronger than the anteroloph. The protolophule joins the short distal arm of the protocone, and the metalophule reaches the short mesial arm of the hypocone. The entoloph is long and angles at the level of the mesocone. The mesoloph is short and the mesostyle is reduced to short cingular elements. Lingually, the entostyle is also reduced.

$\mathrm{M} 2$. The buccal anteroloph is well developed, reaching the buccal corner of the tooth. The lingual anteroloph is thinner, lower and long. The protoloph is oblique forwardly and joins the anterolophule. The posterior arm of the protocone is present. The mesoloph is short. The metalophule is directed anteriorly. A thin entostyle underlines the buccal border of the mesosinus. It differs from the M2 of cf. Heterocricetodon from Santpedor-2 in its smaller size, lophs and mesosinus less transverse and in the different wear pattern (horizontal only on the lingual half of Eucricetodon, the paracone and metacone being bulged and protruding, whereas the buccal cusps of Heterocricetodon are also flattened).

M3. This tiny tooth is too much eroded to depict its features.

Remarks: The small species of Eucricetodon, including atavus, have been referred to the genus Atavocricetodon by Freudenthal (1996), but this author did not give any differential diagnosis with respect to the genus Eucricetodon. A differential diagnosis is also missing in the redescription of the species atavus made by Freudenthal (1988). The validity of Atavocricetodon was then discussed and rejected by other authors (e.g., de Bruijn et al., 2003, Gomes Rodrigues et al., 2013), who "found no obvious reason, even pragmatical, to keep Atavocricetodon as a genus or even a subgenus". This is the reason why we decide here to use Eucricetodon rather than Atavocricetodon. As this cricetid is poorly represented in the locality, we cannot contribute more to this discussion. Its size and morphology fit those of the genus Eucricetodon: bunodont teeth, larger than those of Pseudocricetodon and with simpler lophs and ridges; anterocone of the M1 generally simple, sometimes tending to be slightly duplicated, convex buccal contour of the M1 and posterior lobe of the M3 markedly reduced (Vianey-Liaud, 1972). The size and morphology of the M1 and M2 match those of the lower Oligocene populations of E. atavus (e.g., Hoogbutsel, Aubrelong 1, Ravet, Montalbán, Mège, Pech Crabit, Itardies; Vianey-Liaud, 1972, 1974; Freudenthal, 1988), better than to 'Atavocricetodon' aff. nanus from Valbro (Peigné et al., 2014: fig. 16). The more distinctive difference in size is between the lower $\mathrm{m} 1$ of these two species, but there is no available $\mathrm{m} 1$ in Santpedor-2. If considering the type population of nanus from Valdecollares (Peláez-Campomanes, 1995), the size of the M1 and M2 from Santpedor-2 is clearly larger. Eucricetodon atavus is recorded from MP21 to MP23 (Vianey-Liaud, 1972; Vianey-Liaud and Schmid, 2009).

Subfamily Pseudocricetodontinae Engesser, 1987

Genus Heterocricetodon Schaub, 1925

cf. Heterocricetodon sp.

Fig. 4(F-L)

Material: M1 (distal part): IPS 105273; M2: IPS 105258, 105260; M3: IPS 105267; m1: IPS 105259; m2: IPS 105261; m3: IPS 105263.

Description: We refer the teeth from Santpedor to a small primitive species of Heterocricetodon better than to Pseudocricetodon, on the basis of their rather lophodont dental pattern and the presence of a long mesoloph on one of the M2 (Fig. 4(G)) and on the M3 (Fig. 4(I)). Even if this latter feature is variably found in Pseudocricetodon incertus, it is observed in the material from Santpedor together with other features found in Heterocricetodon: the long lingual anteroloph of M2, the high lophs on the unworn M3; the flat wear surface of the M2 from the lingual edge of the crown to the $2 / 3$ of the occlusal surface, with moderately prominent buccal upper main cusps; the long postmetacristid on $\mathrm{m} 1$ (Fig. $4(\mathrm{~J})$ ), the flat wear surface of the $\mathrm{m} 3$, with its long posterior arm of the protoconid, and the reduced width of its posterior lobe (Fig. 4(L)). The anteroconid and metaconid of $\mathrm{m} 1$ are strongly worn, and therefore the lophids are difficult to distinguish, except the occurrence of a long postmetacristid and a short thick posterior arm of the protoconid, weakly separated from the lingual metalophulid; there are two short mesolophids, the more mesial being the longest. There is no posterior arm of the hypoconid. The fragment of $\mathrm{m} 2$ shows a long postmetacristid ending in a small swelling as a metastylid; its posterior arm of the protoconid is long and oblique towards the base, and ends with a thickening against the middle of the buccal flank of the metaconid; the mesolophid has same length than the posterior arm of the protoconid. Flat and worn on its buccal two-third, its lingual cuspids are not worn. The enamel of the surroundings of the crown is wrinkled.

Remarks: The genus Heterocricetodon was so far unknown in the lower Oligocene. Until now, the earliest species referred to this genus were $H$. landroveri (Daams et al., 1989) from Pareja (MP 26, early Chattian; Aguilar et al., 1997) and $H$. hausi from Bumbach (MP24-25?, earliest Chattian; Engesser, 1987).

As noticed by Engesser (1987: p. 990) for the species hausi, it is difficult to refer isolated teeth to Heterocricetodon, and especially to differentiate them from the genus Pseudocricetodon until the discovery of more abundant material. It is even much more difficult to carry out such a distinction in an older Rupelian locality, where very few teeth are documented. Daams et al. (1989: pp. 47-48) propose to include the species incertus within the genus Heterocricetodon even if cranial features "prove the value of this genus".

The teeth from Santpedor are larger than those of 'PseudoPseudocricetodon' incertus from some lower Chattian localities (Vianey-Liaud et al., 2014: table 5, p. 594) but smaller than H. hausi from Bumbach, and similar in size to H. landroveri ( $\mathrm{m} 1 \mathrm{smaller}$ than the smallest $m 1$ from Pareja, $m 3$ like the largest). The species from 
Santpedor-2 differs from $H$. landroveri in the more reduced posterior lobe of $\mathrm{m} 3$ and the mesoconid more distinct on $\mathrm{m} 1$. Its morphology is closer to $H$. hausi, but the sinus seems less deep buccolingually. As the sample is scarce, we cannot define the morphological and size variability, and prefer to keep this Heterocricetodon sp. in open nomenclature. This species thus represents the earliest record of the genus documented so far.

Genus Pseudocricetodon Thaler, 1969

cf. Pseudocricetodon sp.

Fig. 4(M)

Material: An incomplete m2: IPS 105274.

Description and remarks: This fragment of tooth differs from that ascribed to Heterocricetodon in its slightly smaller size, the enamel smooth, and the more bulbous and rounded main cuspids, as well as in the different arrangement of the talonid basin area. The postmetacristid is shorter and the metastylid less distinct, by contrast there is a mesostylid blocking the opening of the entosinusid. There is no mesolophid distinct from the posterior arm of the protoconid. The latter is widely oblique and is connected to the mesial extremity of the ectolophid: at the junction it curves buccolingually. If this interpretation is right, the mesolophid is absent, because there is no distinct mesoconid, and no ectomesolophid, but only a faint vertical swelling on the buccal flank of the short ectolophid.

Family Gliridae Thomas, 1897

Subfamily Glamyiinae Vianey-Liaud, 1994

Genus Glamys Vianey-Liaud, 1989

Glamys devoogdi (Bosma et de Bruijn, 1979)

Fig. 4(N-P)

Material: p4: IPS 105272; m2: IPS 105270; m2 incomplete: IPS 105271.

Description: The wear surface of p4 (Fig. 4(P)) is nearly flat and the crown relatively low. The metaconid and protoconid are linked by two short and thick lophids: an anterolophid and a metalophulid II. The anterior arm of the hypoconid is faintly developed; therefore, the sinusid is confluent with the posterosynclinid. The posterolophid is long and strong, ending against the bulged entoconid. On $\mathrm{m} 2$, the anterolophid is long, separates from the protoconid and joins the metaconid; the postmetacristid is present and slopes gently to the mesoflexid lingual opening; the metalophid is transverse and thick; the mesoconid is present, and the mesolophid is long, connected to the entoconid by a low entolophid. One extra-ridge (Fig. 4(N)) and granules (Fig. 4(O)) are present in the mesoflexid and posteroflexid.

Remarks: The size of the $\mathrm{p} 4$ and of the complete $\mathrm{m} 2$ fits the size range of Glamys devoogdi from Hamstead Beds and Hoogbutsel (Bosma and de Bruijn, 1979; Vianey-Liaud, 1994) and the morphology is also close to that of this species. On the p4 figured in Bosma and de Bruijn (1979: pl. 2, fig. 5), the mesial connection (anterolophid) is low and does not reach the top of the metaconid and protoconid, whereas this connection is higher and complete on the p4 from Santpedor. The paths of the other extra-ridges and granules, into the sinusid and the talonid, occupy similar positions but their connections vary. The species is recorded from the late Priabonian (MP19/20) to the early Rupelian (MP21).

\section{Discussion}

The Eocene-Oligocene transition was characterized by a drastic decrease in global temperatures, which involved a significant change in the faunas of both marine and terrestrial realms, known as the "Grande Coupure" (e.g., Stehlin, 1910; Prothero, 1994; Zachos et al., 2001; Hooker et al., 2004; Hooker, 2010; Hren et al., 2013). In the European continent this faunal turnover was marked, among other changes, by the arrival of some immigrant groups, such as cricetid rodents (Vianey-Liaud, 1979; Hooker et al., 2004; Maridet and Ni, 2013; Freudenthal and Martín-Suárez, 2016), and by the nearly complete disappearance of primates. Until the end of the $\mathrm{XX}^{\text {th }}$ century, it was generally accepted that microchoerine primates became extinct at the Eocene-Oligocene transition, but the identification of scarce remains of Pseudoloris in Fonollosa and Santpedor (Köhler and Moyà-Solà, 1999) and of Microchoerus in Aguatón (Peláez-Campomanes, 2000) testified to the persistence of this group in the Iberian Peninsula during the earliest Oligocene. For this reason, the detailed study of the fossil sites documenting this time window in Spain is particularly relevant, in order to ensure precise dating of such localities, and to analyze the mammal assemblages that coexisted with these last surviving Paleogene primates in Europe.

The reference faunas of the latest Priabonian (MP20, StCapraise-d'Eymet) and earliest Rupelian (MP21, Soumailles) MPlevels are poor, and have been chosen mainly because they have provided both small and large mammals. However, the evolutionary stages of the documented lineages are not very discriminating, either for the MP20 or for the MP21 (Aguilar et al., 1997). The characterization of the MP20, which is mainly based on the terminal stage of Palaeotherium curtum (sub-species frohnstettense), is not evident (e.g., Hooker, 2010). For the rodents, 'Theridomys' bonduelli could be a good marker, but this species is only known from the Paris and Hampshire basins. This has a definite impact on the precise definition and correlations of faunas around the "Grande Coupure".

The "Grande Coupure" would mark the base of the Rupelian, currently dated at 33.9 Ma (Vandenberghe et al., 2012). Several correlation attempts with respect to mammalian lineages have been made, using magnetostratigraphy and geochemistry (Solent Group, Whitecliff Bay, Isle of Wight, England; Gale et al., 2006; Hooker et al., 2009) or only magnetostratigraphy in the case of the Santpedor section (Barberà et al., 2001; Costa et al., 2011). According to the latter authors, the magnetostratigraphic location of the MP21 level, possibly represented at Santpedor at the upper part of the $13 \mathrm{r}$ chron, would date this MP around 33.4 Ma, but this datum needs to be confirmed. This locality contains both immigrant rodents, such as the Cricetidae, as well as native species of Gliridae and Theridomyidae. The scarcity of rodent material in the MP20 and MP21 reference levels, combined with the geographical differentiation observed between theridomyoids at the beginning of the Oligocene, does not facilitate precise correlations. Nonetheless, it is easy to identify the arrival of immigrant taxa and also to distinguish the evolutionary stages of certain lineages when they have represented by sufficient teeth.

There are currently few Rupelian and earliest Chattian MP, four in number (MP21 to MP24), over a total stage duration of $\sim 6$ myr. However, based on the evolutionary degrees of several Theridomyoidea lineages, at least one intermediate level MP23/24 can be inserted even if it has not yet been formally defined (Fig. 5). It would correspond to the evolutionary level of the fauna from StMartin-de-Castillon (Vaucluse), in particular to the species Protechimys truci (Hugueney, 1994; Vianey-Liaud, 1998; VianeyLiaud and Marivaux, 2017). The standard locality of MP24 (Heimersheim) is located at the base of the Cyrenen Mergel, and correlated with the Kasseler Meeressand, which provided nannoplankton from the NP24 area (Bahlo, 1975: p. 12). Thus, the age of MP24 is close to the Rupelian-Chattian boundary (28.3 Ma; Vandenberghe et al., 2012) within the lowermost Chattian.

The study of the rodents from Santpedor-2 reveals a higher diversity than previously thought. Even if the number of rodent teeth is small, they are characteristic enough either to be identified as already known species, or at least compared to morphologically close species. Among them, one species is known only from late 


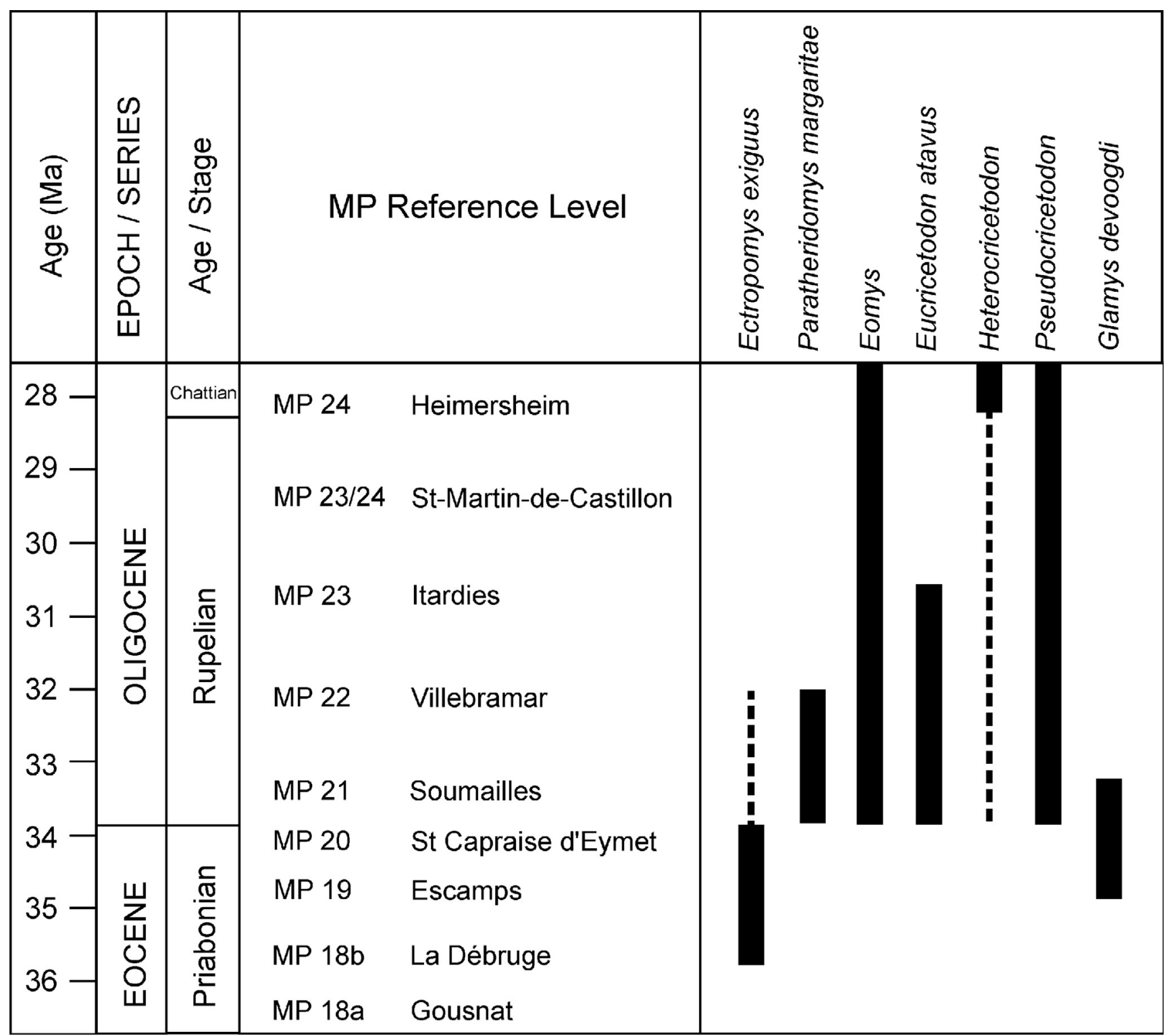

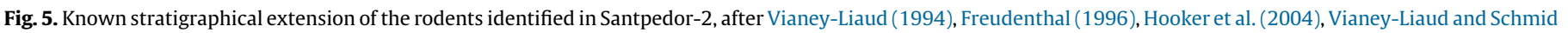

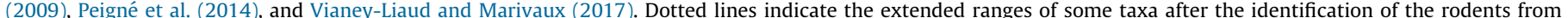

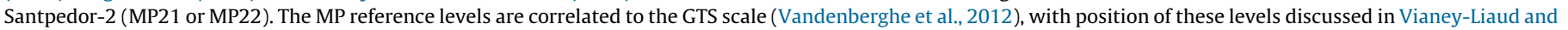

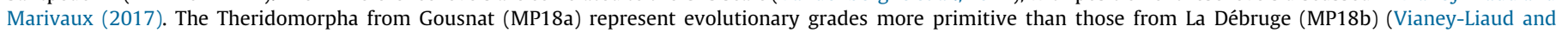
Marivaux, 2017).

Eocene localities (MP18 to MP20): the Theridomyidae Ectropomys exiguus (Vianey-Liaud et al., 1994). The glirid Glamys devoogdi is known from late Priabonian to early Rupelian localities (MP19 to MP21; Vianey-Liaud, 1994: table 2). The other identified rodents belong exclusively to Oligocene taxa (Fig. 5). One Theridomyidae (Paratheridomys margaritae) is known from the standard locality of MP21 (Hoogbutsel, Belgium; Vianey-Liaud, 1972), which is the type locality of the species, and from La Plante 2 (Quercy, France, MP22; Vianey-Liaud, 1989). The other Theridomyidae (?Issiodoromyinae) is probably a new species, and perhaps a new genus; its features (e.g., size of premolars) better indicate Oligocene rather than late Eocene evolutionary grades. Two immigrant families of the "Grande Coupure" are recognized: the Eomyidae and the Cricetidae, among which one species (Eucricetodon atavus) and one genus (Pseudocricetodon) are recorded since MP21. The other genera are represented by original species, a Heterocricetodon more primitive, smaller, and plausibly older than the earliest species known until now, and an Eomys larger than the MP21 species E. antiquus, but with features different from all known Eomys species.

This rodent assemblage is most probably early Oligocene in age, with a certain diversity of well-characterized immigrant families, and Oligocene evolutionary grades of autochthonous lineages (i.e., P. margaritae and G. devoogdi). One rodent species (Ectropomys exiguus) represents an Eocene relict, as is the case of Pseudoloris godinoti, the only primate recorded in this locality. As there are only 33 teeth for eight rodent species found so far, some of them remain in open nomenclature, and therefore we cannot precise if the assemblage is close to MP21 or to MP22. Further field campaigns in this fossil site, leading to the recovery of more abundant material, will probably allow for more precise taxonomic determinations and a more accurate dating of the locality. 


\section{Conclusions}

The rodent fossil material from Santpedor-2 (Ebro Basin, NE Spain) was described in detail for the first time. The assemblage includes eight different rodent taxa: Ectropomys exiguus, Paratheridomys margaritae, ?Issiodoromyinae nov. gen., nov. sp., Eomys sp., Eucricetodon atavus, cf. Heterocricetodon sp., cf. Pseudocricetodon sp., and Glamys devoogdi; it is notably different from that reported in the preliminary faunal lists provided by Agustí et al. (1987) and Arbiol and Sáez (1988). Although the locality has yielded one species that can be considered as an Eocene relict (Ectropomys exiguus), the presence of two rodent families that arrived in Europe as part of the "Grande Coupure" event (Eomyidae and Cricetidae), as well as the evolutionary grade of species of Gliridae and Theridomyidae, might indicate an early Oligocene age for this assemblage. Nevertheless, the scarcity of the material prevents a precise taxonomic determination of some taxa and a conclusive assignment to one of the earliest Oligocene standard levels (MP21 or MP22). In any case, this study confirms the early Oligocene age of Santpedor-2, one of the few European localities that documents the persistence of omomyid primates after the "Grande Coupure".

\section{Acknowledgements}

We are truly grateful to the editor G. Escarguel and three anonymous reviewers for their constructive comments that greatly improved the manuscript. This work has been supported by the CERCA Programme/Generalitat de Catalunya, the project CGL2017-82654-P, MINECO/FEDER, UE (Ministerio de Economía, Industria y Competitividad, Spanish Government and European Union), and the research groups 2017 SGR 86 GRC (Generalitat de Catalunya) and RNM190 (Junta de Andalucía). R. M.-B. is funded by the Plan Propio de Investigación, Vicerrectorado de Investigación y Transferencia, Universidad de Granada. This work has made use of the collections of the Institut des Sciences de l'Évolution de Montpellier (ISE-M, UMR 5554). Publ. ISEM n ${ }^{\circ}$ 2019-125.

\section{References}

Aguilar, J.P., Legendre, S., Michaux, J., 1997. Synthèses et tableaux de corrélations. In: Aguilar, J.P., Legendre, S., Michaux, J. (Eds.), BiochroM'97 : biochronologie mammalienne du Cénozoïque en Europe et domaines reliés. Actes du Congrès BiochroM'97. École Pratique des Hautes Études Institut de Montpellier, Montpellier, pp. 769-805.

Agustí, J., Anadón, P., Arbiol, S., Cabrera, L., Colombo, F., Sáez, A., 1987. Biostratigraphical characteristics of the Oligocene sequences of North-Eastern Spain (Ebro and Campins Basins). Münchner Geowissenschaftliche Abhandlungen 10, 35-42.

Anadón, P., Vianey-Liaud, M., Cabrera, L., Hartenberger, J.L., 1987. Gisements à vertébrés du paléogène de la zone orientale du bassin de l'Ebre et leur apport à la stratigraphie. Paleontologia i Evolució 21, 117-131.

Arbiol, S., Sáez, A., 1988. Sobre la edad oligocénica inferior del yacimiento de Santpedor (Cuenca del Ebro, provincia de Barcelona). Acta Geológica Hispánica 23, 47-50.

Bahlo, E., 1975. Die Nagetierfauna von Heimersheim bei Alzey (Rheinhessen Westdeutschland) aus dem Grenzbereich MittellOberoligozän und ihre stratigraphische Stellung. Abhandlungen Hessisches Landesamt für Bodenforschung 71, 1182.

Barberà, X., Cabrera, L., Marzo, M., Parés, J.M., Agusti, J., 2001. A complete terrestrial Oligocene magnetobiostratigraphy from the Ebro Basin Spain. Earth and Planetary Science Letters 187, 1-16.

Bonilla-Salomón, I., Minwer-Barakat, R., Vianey-Liaud, M., Moyà-Solà, S., 2016. Middle Eocene rodents from Sant Jaume de Frontanyà-1 (Eastern Pyrenees, Northern Spain) and biochronological implications. Journal of Vertebrate Paleontology 36, e1121149.

Bosma, A.A., de Bruijn, H., 1979. Eocene and Oligocene Gliridae (Rodentia, Mammalia) from the Isle of Wight, England. Part 1. The Gliravus priscus - Gliravus ford lineage. Proceedings Koninklijke Nederlandse Akademie van Wetenschappen, B 82, 367-384.

Bosma, A.A., Schmidt-Kittler, N., 1972. Ectropomys exiguus n. gen., n. sp., member of the Oltinomyinae n. subfam. (Theridomyidae Rodentia), from Paleogene deposits of the Isle of Wight (England) and southem Germany. Proceedings Koninklijke Nederlandse Akademie van Wetenschappen 75, 181-192.
Busquets, P., Serra-Kiel, J., Ferrández-Cañadell, C., 2003. New advances in Eocene Biostratigraphy (IGCP Project No. 393): a contribution from the Southeastern Pyrenean Foreland Basin. Geológica Acta 1, 151-238.

Comte, B., Vianey-Liaud, M., 1989. Eomyidae (Rodentia) de l'Oligocène d'Europe Occidentale. Palaeontographica A 209, 33-91.

Costa, E., Garcés, M., López-Blanco, M., Beamud, E., Gómez-Paccard, M., Larrasoaña, J.C., 2010. Closing and continentalization of the South Pyrenean foreland Basin (NE Spain): magnetochronological constraints. Basin Research 22, 904-917.

Costa, E., Garcés, M., Sáez, A., Cabrera, L., López-Blanco, M., 2011. The age of the "Grande Coupure" mammal turnover: new constraints from the Eocene-Oligocene record of the Eastern Ebro Basin (NE Spain). Palaeogeography, Palaeoclimatology, Palaeoecology 301, 97-107.

Crusafont-Pairó, M., 1967. Sur quelques prosimiens de l'Éocène de la Zone Préaxiale Pyrénaique et un essai provisoire de reclassification. Colloque internationaux du C.N.R.S. 163, 611-632.

Cuenca, G., Canudo, J.I., Laplana, C., Andrés, J.A., 1992. Bio y cronoestratigrafía con mamíferos en la Cuenca Terciaria del Ebro: ensayo de síntesis. Acta Geológica Hispánica 27, 127-143.

Daams, R., Freudenthal, M., Lacomba, J.J., Álvarez, M.A., 1989. Upper Oligocene micromammals from Pareja, Loranca Basin, prov. of Guadalajara, Spain. Scripta Geologica 89, 27-56.

Daxner-Höck, G., Höck, E., 2009. New data on Eomyidae and Gliridae (Rodentia Mammalia) from the Late Miocene of Austria. Annalen des Naturhistorischen Museums in Wien 111, 375-444.

de Bruijn, H., Unay, E., Saraç, G., Yilmaz, A., 2003. A rodent assemblage from the Eo/ Oligocene boundary interval near Süngülü, Lesser Caucasus Turkey. Coloquios de Paleontología 1, 47-76.

Dienemann, A., 1987. Die gattungen Eucricetodon und Pseudocricetodon (Rodentia, Mammalia) aus dem Oligozän Süddeustchlands. Bayerische Akadenie der Wissenschaften. Mathematische-Naturwissenschaftliche klasse 165, 1-158.

Engesser, B., 1987. New Eomyidae, Dipodidae and Cricetidae (Rodentia Mammalia) of the Lower Freshwater Molasse of Switzerland and Savoy. Eclogae Geologicae Helvetiae 80, 943-994.

Freudenthal, M., 1988. Redescription of Eucricetodon atavus (Misonne, 1957) (Rodentia) from Hoogbutsel (Belgium). Bulletin de l'Institut royal des Sciences naturelles de Belgique 58, 199-207.

Freudenthal, M., 1996. The Early Oligocene rodent fauna of Olalla 4A (Teruel Spain). Scripta Geologica 112, 1-67.

Freudenthal, M., Martín-Suárez, E., 2016. A review of Oligocene and early Miocene European Cricetidae (Mammalia). Spanish Journal of Palaeontology 31, 341352.

Gale, A.S., Huggett, J.M., Pälike, H., Laurie, E., Hailwood, E.A., Hardenbol, J., 2006. Correlation of Eocene-Oligocene marine and continental records: orbital cyclicity, magnetostratigraphy and sequence stratigraphy of the Solent Group, Isle of Wight UK. Journal of the Geological Society 163, 401-415.

Garzon Heydt, G., López Martínez, N., 1978. Los roedores fósiles de los Barros (Ávila) Datación del Paleógeno continental en el Sistema Central. Estudios Geológicos 34, 571-575

Golpe, J.M., 1982. Paleobiologia dels jaciments amb vertebrats al trànsit EocèOligocè a la Catalunya central. Butlletí de la Institució Catalana d'Història Natural 48, 123-134.

Gomes Rodrigues, H., Marivaux, L., Vianey-Liaud, M., 2013. On the status of early Eucricetodontinae (Muroidea Rodentia) with a special focus on the Atavocricetodon vs. Eucricetodon issue: morphometrical and microstructural aspects. Spanish Journal of Palaeontology 28, 17-27.

Hooker, J.J., 2010. The "Grande Coupure" in the Hampshire Basin UK: taxonomy and stratigraphy of the mammals on either side of this major Paleogene faunal turnover. In: Whittaker, J.E., Hart, M.B. (Eds.), Micropalaeontology, Sedimentary Environments and Stratigraphy: A Tribute to Dennis Curry (1912-2001). The Micropalaeontological Society, Special Publications, Geological Society of London, London, pp. 147-215.

Hooker, J.J., Collinson, M.E., Grimes, S.T., Sille, N.P., Mattey, D.P., Gale, A., Huggett, J., Laurie, E., 2007. Discussion on the Eocene-Oligocene boundary in the UK. Journal of the Geological Society 164, 685-688.

Hooker, J.J., Collinson, M.E., Sille, N.P., 2004. Eocene-Oligocene mammalian faunal turnover in the Hampshire Basin, UK: calibration to the global time scale and the major cooling event. Journal of the Geological Society 161, 161-172.

Hooker, J.J., Grimes, S.T., Mattey, D.P., Collinson, M.E., Sheldon, N.D., 2009. Refined correlation of the UK Late Eocene-Early Oligocene Solent Group and timing of its climate history. In: Koeberl, C., Montanari, A. (Eds.), The Late Eocene EarthHothouse, Icehouse and Impacts. The Geological Society of America, Special Paper 452, Boulder, Colorado, USA, pp. 179-195.

Hren, M.T., Sheldon, N.D., Grimes, S.T., Collinson, M.E., Hooker, J.J., Bugler, M., Lohmann, K.C., 2013. Terrestrial cooling in Northern Europe during the Eocene-Oligocene transition. Proceedings of the National Academy of Sciences of the United States of America 110, 7562-7567.

Hugueney, M., 1994. Theridomys truci de l'Oligocène de Saint- Martin-de-Castillon (Vaucluse, France), nouvelle espèce du genre Theridomys (Rodentia, Mammalia) et sa relation avec la lignée de Theridomys lembronicus. Scripta Geologica 104, 115-127

Köhler, M., Moyà-Solà, S., 1999. A finding of Oligocene primates on the European continent. Proceedings of the National Academy of Sciences of the United States of America 96, 14664-14667.

Maridet, O., Hugueney, M., Heissig, K., 2010. New data about the diversity of Early Oligocene eomyids (Mammalia Rodentia) in western Europe. Geodiversitas 32, 221-254. 
Maridet, O., Ni, X., 2013. A new cricetid rodent from the early Oligocene of Yunnan, China, and its evolutionary implications for early Eurasian cricetids. Journal of Vertebrate Paleontology 33, 185-194.

Marigó, J., Susanna, I., Minwer-Barakat, R., Madurell-Malapeira, J., Moyà-Solà, S., Casanovas-Vilar, I., Robles, J.M., Alba, D.M., 2014. The primate fossil record in the Iberian Peninsula. Journal of Iberian Geology 40, 179-211.

Masachs, V., Crusafont, M., Villalta, J.F., 1954. Sur l'âge du gisement potassique de la Catalogne. Compte Rendu Sommaire des Séances de la Société géologique de France 13, 304-305.

Minwer-Barakat, R., Marigó, J., Femenias-Gual, J., Moyà-Solà, S., 2015. New material of Pseudoloris parvulus (Microchoerinae, Omomyidae, Primates) from the Late Eocene of Sossís (northeastern Spain) and its implications for the evolution of Pseudoloris. Journal of Human Evolution 83, 74-90.

Minwer-Barakat, R., Marigó, J., Moyà-Solà, S., 2010. A New Species of Pseudoloris (Omomyidae, Primates) from the Middle Eocene of Sant Jaume de Frontanyà (Eastern Pyrenees Spain). American Journal of Physical Anthropology 143, 9299.

Minwer-Barakat, R., Marigó, J., Moyà-Solà, S., 2012. Pseudoloris cuestai, a new microchoerine (Primates Omomyidae) from the Middle Eocene of the Iberian Peninsula. Journal of Vertebrate Paleontology 32, 407-418.

Minwer-Barakat, R., Marigó, J., Moyà-Solà, S., 2013. Redescription and designation of a neotype for Pseudoloris reguanti Crusafont-Pairó, 1967, an Eocene primate from the Iberian Peninsula. American Journal of Physical Anthropology 151, 245-251.

Minwer-Barakat, R., Marigó, J., Moyà-Solà, S., 2016. On the determination of the Microchoerus (Omomyidae, Primates) remains from Sant Cugat de Gavadons (Late Eocene, Ebro Basin NE Spain). American Journal of Physical Anthropology $160,162-168$.

Peigné, S., Vianey-Liaud, M., Pélissié, T., Sigé, B., 2014. Valbro : un nouveau site à vertébrés de l'Oligocène inférieur (MP22) de France (Quercy). I - Contexte géologique ; Mammalia : Rodentia, Hyaenodontida Carnivora. Annales de Paléontologie 100, 1-45.

Peláez-Campomanes, P., 1995. Valdecollares: a rodent fauna from the lower Oligocene of the Loranca Basin (Cuenca Spain). Proceedings Koninklijke Nederlandse Akademie van Wetenschappen 98, 265-289.

Peláez-Campomanes, P., 2000. Mammalian faunas from the Paleogene of the Sierra Palomera (Teruel, Spain). Journal of Paleontolology 74, 336-348.

Prothero, D.R., 1994. The late Eocene-Oligocene extinctions. Annual Reviews of the Earth and Planetary Sciences 22, 145-165.

Puigdefàbregas, C., Muñoz, J.A., Vergés, J., 1992. Thrusting and Foreland Basin Evolution in the Southern Pyrenees. In: McClay, K.R. (Ed.), Thrust Tectonics. Chapman and Hall, London, pp. 247-254.

Sáez, A., Anadón, P., Herrero, M.J., Moscariello, A., 2007. Variable style of transition between Palaeogene fluvial fan and lacustrine systems, southern Pyrenean foreland, NE Spain. Sedimentology 54, 367-390.
Sanjuan, J., Martín-Closas, C., Costa, E., Barberà, X., Garcés, M., 2014. Calibration of Eocene-Oligocene charophyte biozones in the Eastern Ebro Basin (Catalonia Spain). Stratigraphy 11, 61-81.

Stehlin, H.G., 1910. Remarques sur les faunules de Mammifères des couches Éocènes et Oligocènes du Bassin de Paris. Bulletin de la Société Geologique de France 9, 488-520.

Vandenberghe, N., Hilgen, F.J., Speijer, R.P., 2012. The Paleogene Period. In: Gradstein, F.M., Ogg, J.G., Schmitz, M.D., Ogg, G.M. (Eds.), The Geologic Time Scale 2012. Elsevier, Oxford, pp. 855-921.

Vianey-Liaud, M., 1972. L'évolution du genre Theridomys à l'Oligocène moyen. Intérêt biostratigraphique. Bulletin du Museum National d'Histoire Naturelle, Paris 98, 295-372.

Vianey-Liaud, M., 1974. L'anatomie des genres Eucricetodon et Pseudocricetodon (Cricetidae, Rodentia Mammalia). Géologie Méditerranéenne 1, 111-132.

Vianey-Liaud, M., 1976. Les Issiodoromyinae (Rodentia Theridomyidae) de l'Eocène supérieur à l'Oligocène supérieur en Europe occidentale. Palaeovertebrata 7,1115.

Vianey-Liaud, M., 1979. Evolution des rongeurs à l'Oligocène en Europe Occidentale. Palaeontographica A 166, 136-236.

Vianey-Liaud, M., 1989. Parallélisme chez les Theridomyinae (rodentia) de l'Oligocène : étude de deux nouvelles espèces des genres Theridomys et Blainvillimys. Neues Jahrburg Geologie und Paläontologie Abhandlungen 178, 203-241.

Vianey-Liaud, M., 1994. La radiation des Gliridae (Rodentia) à l'Eocène supérieur en Europe Occidentale, et sa descendance Oligocène. Münchner Geowissenschaftliche Abhandlungen 26, 117-160.

Vianey-Liaud, M., 1998. La radiation des Theridomyidae (Rodentia) à l'Oligocène inférieur : modalités et implications biochronologiques. Geologica et Palaeontologica 32, 253-285.

Vianey-Liaud, M., Comte, B., Marandat, B., Peigné, S., Rage, J.-C., Sudre, J., 2014. A new early Late Oligocene (MP 26) continental vertebrate fauna from SaintPrivat-des-Vieux (Alès Basin, Gard Southern France). Geodiversitas 36, 565 622.

Vianey-Liaud, M., Marivaux, L., 2017. Autopsie d'une radiation adaptative : Phylogénie des Theridomorpha, rongeurs endémiques du Paléogène d'Europe histoire, dynamique évolutive et intérêt biochronologique. Palæovertebrata, Monograph 40, 1-68.

Vianey-Liaud, M., Schmid, B., 2009. Diversité, Datation et Paléoenvironnement de la faune de mammifères oligocène de Cavalé (Quercy, SW France) : contribution de l'analyse morphométrique des Theridomyinae (Mammalia Rodentia). Geodiversitas 31, 909-941.

Vianey-Liaud, M., Schmidt-Kittler, N., Peláez-Campomanes, P., 1994. Pairomys et Ectropomys : la fin d'une ambiguïté ; mise au point sur les Oltinomyinae et les Remyinae (Rodentia, Theridomyinae). Palaeovertebrata 23, 119-152.

Zachos, J., Pagani, M., Sloan, L., Thomas, E., Billups, K., 2001. Trends, rhythms and aberrations in global climate 65 Ma to present. Science 292, 686-693. 